\title{
"REMEMBERING IS OUR MUNITY": \\ AN EXAMINATION OF EXILE, MEMORY, AND PALESTINIAN \\ IDENTITY IN SALT HOUSES
}

by

Lena Lahalih, BA (Hons), Ryerson University, 2018

\author{
A Major Research Paper \\ presented to Ryerson University \\ in partial fulfillment of the \\ requirements for the degree of \\ Master of Arts \\ in the English MA Program \\ in Literatures of Modernity
}

Toronto, Ontario, Canada, 2019

CLena Lahalih 2019 


\section{AUTHOR'S DECLARATION FOR ELECTRONIC SUBMISSION OF A MAJOR RESEARCH PAPER}

I hereby declare that I am the sole author of this MRP. This is a true copy of the MRP, including any required final revisions.

I authorize Ryerson University to lend this MRP to other institutions or individuals for the purpose of scholarly research. I further authorize Ryerson University to reproduce this MRP by photocopying or by other means, in total or in part, at the request of other institutions or individuals for the purpose of scholarly research.

I understand that my MRP may be made electronically available to the public. 


\section{Acknowledgements}

I would like to express my sincere gratitude to my supervisor Dr. Nima Naghibi. This work would have not been possible without her invaluable support and guidance throughout this long endeavour. As a former undergraduate student at Ryerson University, I admired her ability to weave cultural and political history, and critical theory into her work on Iranian diasporic writing. It was a great privilege to work under her guidance, as I pursued my own research on Palestinian-Israeli history, identity, and memory. In particular, would like to thank her for empathy and support during the writing and editing stages of my paper.

I would also like to thank Dr. Lauren Kirshner for her guidance, comments, and suggestions during the final stages of my work. 


\author{
"Remembering is Our Munity": \\ An Examination of Exile, Memory, and Palestinian Identity \\ in Salt Houses
}

"[W] hat is true of all exiles is not that home and love of home are lost, but that loss is inherent in the very existence of both."- Edward Said, "Reflection on Exile" (1984)

Watan means homeland in Arabic. For exiled Palestinians, the politically charged term evokes a painful memory of home, loss, and expulsion from a land they were forced to flee in 1948. The 1948 Israeli-Arab War which led to the creation of the State of Israel, also resulted in the devastation of Palestinian society. This period is regarded by Palestinians as the nakba, or the catastrophe, which saw the displacement and expulsion of over 800,000 Palestinians from their communities (Gelvin 236). Approximately 80 percent of the Palestinians who lived in the major part of Palestine, upon which Israel was established, became refugees (Abu-Lughod and Sa'di 3). The minority of Palestinians who remained in the newly-minted state became "nominal citizens" and were subject to a separate system of "military administration" (3). In the same year, those who had stayed witnessed the systematic annexation of their lands (Abu-Lughod 3). Others became internally-displaced refugees and sought refuge in places like the West Bank and the Gaza Strip, which were under the control of Jordan and Egypt respectively (Gelvin 240). Thus, historic Palestine became "a society disintegrated, a people dispersed, and a complex and historically changing but taken for granted communal life was violently ended" (Abu-Lughod and Sa'di 3).

The destruction of Palestinian society was overshadowed by the symbolic meaning attached to the State of Israel. The loss of the Palestinian watan coincided with the creation of a state which represented the "rebirth" of European Jewry. Lila Abu-Lughod and Ahmed Sa'di note that the death-rebirth dialectic, a "philosophical conception with enormous purchase in both 
religious and secular Western thought," was applied to the condition of the Jewish people in Europe (4). The creation of the State of the Israel was regarded as an act of restitution which sought to bring good and establish a safe haven for Jews who had escaped rampant persecution in Europe, including the evils of the Holocaust which saw the ethnic cleaning of 6 million Jews during World War II.

The Palestinians were excluded from this unfolding history: their catastrophe was either disregarded or reduced to a "question of ill-fated refugees" (4). The watan was excluded from the historiography of the region, whose right to independence, statehood, and very existence were denied. In his essay “Out of Place, Out of Time," Palestinian historian Elias Sanbar writes of the exclusion of Palestinians from contemporary history:

The contemporary history of the Palestinians turns on a key date: 1948. That year, a country and its people disappeared from maps and dictionaries... "The Palestinian people does not exist," said the new masters, and henceforth the Palestinians would be referred to by general, conveniently vague terms, as either "refugees," or in the case of a small minority that had managed to escape the generalized expulsion, "Israeli Arabs." A long absence was beginning. (Sanbar 87)

Following the year 1948, the lives of Palestinians were dramatically altered at the level of the individual, the community, and the nation. The nakba remains a crucial cultural memory in Palestinian history, one which cannot be separated from the past, present, or future developments in the region. Seventy years later, the nakba continues to be, in Palestinian traumatic social 
memory and history, the baseline for personal histories and the scattering of generations across the diaspora.

Salt Houses, the first novel by Palestinian-American writer, Hala Alyan examines trauma, intergenerational memory, and displacement faced by the Yacoub family over the span of four generations. The novel opens with Salma Yacoub, the matriarch of the family, who reads her daughter's fate into her empty coffee cup. The prediction haunts her: she sees a life full of hardship for Alia and her family, but she also sees travel and fortune. Four years later, the family is uprooted from their homes in the wake of the Six-Day War of 1967. Salma is forced to leave Nablus to move to Amman; Mustafa, her son, is caught in a whirlwind of political militancy, which results in his death; Alia and her husband move to Kuwait City in an attempt to build a new life with their three children Riham, Souad, and Karam. Several decades later, the third generation of the Yacoub family are uprooted from their homes once again, when Saddam Hussein invades Kuwait. Alia and her family members scatter to all corners of the world such as Amman, Boston, Paris, and Beirut. Each of Alia's children grow up to have families of their own, and once again the burden of the family's traumatic history is passed on to the next generation: Zain, Linah, Manar, and Abdullah. Each character carries with them the memories of their predecessors as they navigate their lives in foreign cities, far removed from the place of origin. Salt Houses illustrates the significance of the nakba in both Palestinian social and personal memory, and at the same time highlights the importance of an original homeland in the lives of Palestinians.

This paper will examine the process through which the Yacoubs' collective traumatic memory strengthens the connections the characters have to Palestine. I will make the distinction between exiled and diasporic characters based on their proximity to Palestine. I consider Salma, 
Alia, and Atef, all born and raised in Palestine, as exiles because of the trauma of violence and dislocation they experience in 1948 and 1967. On the other hand, I consider characters such as Riham, Karam, Souad and their children Linah, Zain, Manar, and Abdullah as members of the Palestinian diaspora. All of them are born outside of Palestine, have not directly experienced trauma in the region, but they nevertheless carry the legacy of traumatic memories as experienced by the previous generations. Alyan's depiction of the Yacoub family underscores the complexity of inherited memory and identity. Ultimately, Salt Houses emphasizes the importance of a physical homeland in the family's legacy, four generations after their personal nakba. Although every generation of the Yacoub family experiences a degree of alienation as a result of self-imposed exile or forced displacement, I argue that it is the Yacoubs' intergenerational memories, passed down through oral and written testimonies, that consolidate the family's original link to Palestine. Furthermore, intergenerational memories pave the way for healing amongst exiled characters: while female characters such as Salma and Alia heal through oral testimony, Atef heals through letter writing and confessionals. Finally, the transfer of the memories to the diasporic generation allow the family to reconcile with their own trauma legacy, receiving the closure they were once denied of.

The nakba is the site of competing memory for both Palestinians and Israelis; while the former group remembers 1948 as a period of hardship and suffering, the latter group regard the same period as a year of triumphant victory in the establishment of a Jewish homeland.

Palestinian records of trauma, pain, and devastation are often overlooked by mainstream Western academic institutions, due to a long tradition of "deep-seated cultural bias, and the fear of antiSemitism" (Sayigh 58). Rosemary Sayigh argues that the exclusion of the nakba from trauma studies "both reflects and reinforces the marginalization of Palestinian claims to justice and the 
recognition of the Nakba in world politics" (57). Nevertheless, scholars such as Lila AbuLughod, Edward Said, and Diana K. Allan, among others, have written extensively on the Palestinian nakba, exile, and cultural memory, solidifying its connection to Western trauma theory and memory.

For Palestinians, the memory of the nakba is regarded as the main entry point into their grief. The cumulative testimonies of those who have experienced loss during the nakba is engraved into Palestinian memory. Nuala C. Johnson argues that popular memory "can be a vehicle through which dominant, official renditions of the past can be resisted by mobilizing groups toward social action, but also through the maintenance of an opposition group identity embedded in subaltern memories" (Johnson 174). Scholarship on the Palestinian experience of the nakba presents its own set of challenges when read against Israeli counter-narratives of the same period. Firstly, the catastrophe, in all aspects, has not just determined the fate of Palestinian civilians but has since then become the site of Palestinian collective traumatic memory (Khalidi 55). Secondly, the memory of the nakba affirms a Palestinian identity as well as a legitimate claim to a Palestinian homeland. These two important points have, and continue to be, a contentious issue in many Israeli and Palestinian sociopolitical discourses. However, it is important to recognize that any past, present, and future developments in the region are inextricably linked to the nakba. For this reason, the nakba, is seen as the "demarcation line between two qualitatively opposing periods" (Abu-Lughod and Sa'di 4): pre-nakba and postnakba life. For many Palestinians who remain dispossessed of a homeland, the past is neither distant nor over.

One of the most defining qualities of Palestinian social memory, according to Lila AbuLughod and Ahmed Sa'di, is its "orientation to place" (Abu-Lughod and Sa'di 13). The narrative 
foregrounds the family's exile from Jaffa — the seaside town that would later become a part of the city of Tel Aviv - in 1948 as the original loss, a loss which permeates the story's events in the subsequent displacement and the characters' understanding of them. Salt Houses moves from place to place and shifts perspectives, in order to illustrate the significance of Palestinian nationhood, identity, and trauma in the production of Palestinian sociocultural memory. Katherine Hodgkin and Susannah Radstone remind us that:

The memory of individual actors in $[\ldots]$ trauma is solicited in order to cure the entire society; the production of history is thus tied to a narrative of disclosure, closure, and reconciliation, along with the particular model of the relation between past and present that the traumatic narrative implies. (9)

For the Yacoubs in Salt Houses, Jaffa symbolizes all that has been lost, and a memory of a land to which return is barred. Although the legacy of Salma and Hussam's traumatic displacement from Jaffa is central to the novel's plot, the memory also serves as a testament to the unique quality of the Palestinian experience. Palestinians often remember the abrupt displacement of their families from their lands, the continuation of violence and the lack of resolution in the region. Most importantly, the "political nature of the deliberate erasure" of Palestinian testimonies and stories (Abu-Lughod and Sa'di 4-5), poses a threat to unreconciled trauma. The reluctance to acknowledge the memory of the nakba as a legitimate source of pain, complicates the healing process Palestinians must undertake as victims.

Salt Houses, like other Palestinian fictional narratives, contains multilayered perspectives which include "the immigrant narrative over a transitional narrative over a formative refugee 
narrative" (McCullough 805). However, Alyan's novel brilliantly employs a complex layering of spaces and temporalities, bringing forth discourses of localized Palestinian narratives of trauma into globalized contexts. Although the narrative begins with the family's original displacement from Jaffa, told from the perspective of Salma Yacoub, her son Mustafa, and her daughter Alia, the memory of their nakba is negotiated by every subsequent generation. Characters such as Hussam and Salma, Alia and her husband Atef struggle to reconcile their own grief with the impending displacement they face as an unfortunate consequence of war. As a result, the nakba prevents these characters away from living in the present moment, and instead, pushes them into their own specific history and often into a melancholic existence. However, the novel emphasizes the importance of oral and written testimonies as a means of healing from the past for the victim, while simultaneously preserving the memory for the next generation.

Primary written records of the nakba relay a long history of military conflict, exile, and melancholy (Humphries and Khalili 207). These records foreground the voices of male Palestinian elitist and nationalist leaders (209). Great importance is placed on testimonies from poets such as Mahmoud Darwish, Nizar Qabbani, and journalists such as Ghassan Kanafani and Daoud El-Issa over those of their female Palestinian counterparts. In accordance with Palestinian tradition, a man's perspective on the affairs of the watan is prioritized because his honour is bound up with the possession of land and the obligation to provide for one's family; lineage and ethnicity are also passed on through the father. However, it is the memories of ordinary Palestinian women which have "quietly imbued generation after generation of Palestinians with concrete, tangible, and colorful details of life and loss" (209). In Salt Houses, Salma's memories and stories of the "villa, painted color of peach flesh, that had been their home," (Alyan 1) 
cements the family's lineage and historic connection to the land, while also marking Jaffa as a significant site of personal and traumatic memory.

Other characters like Manar, Linah, Zain, and Abdullah, born and raised in the diaspora, inherit the memories of Palestine from the generations before them, through the process of what Marianne Hirsch calls "postmemory." Hirsch coined the term to describe the way younger generations "grow up dominated by narratives that preceded their own birth, whose own belated stories are displaced by the stories of a previous generation, shaped by traumatic events that can neither be understood nor recreated" (Hirsch 22). The grandchildren in the novel discover the diary of their grandfather Atef, which details an account of the family's personal history, including his confessions regarding his complicity in the arrest and torture of his brother-in-law, Mustafa, at the hands of Israeli soldiers. For the grandchildren, the places of the pre-nakba past and the land of Palestine itself are signifiers of their heritage and history. They are not simply sites of memory but symbols of all that has been lost and sites of longing to which return is no longer possible.

Salt Houses opens in Nablus in 1963, where Salma Yacoub is performing a reading of her daughter's coffee cup before her wedding. The cup was part of a set she had bought when she relocated to Nablus with her husband nearly fifteen years before. In the marketplace, Salma notices an ibrik (coffee pot) with matching cups which reminds her of a similar set her mother had gifted her in Jaffa: "but it was gone, the old tray and coffee set, along with so many of their belongings, the dresses and walnut furniture and Hussam's books. All left behind in that villa, painted the color of peach flesh, that had been their home" (Alyan 1). Jaffa was the city where Salma was born, where she met and married her husband Hussam, and where they decided to raise their family. Their villa could be found on a small hill that overlooked the sea, surrounded 
by orange groves (5). Salma hails from a poor family and was raised on a steady diet of lentils and bread, until she married into an upper-class family. Salma's life of wealth and privilege is cut short in 1948, when the war breaks out: "[Alia, her daughter] was barely three when the Israeli army rolled through Jaffa's streets, the tanks smashing the marketplace, the soldiers dragging half-sleeping men from their homes. There would be the birth of a new nation, they declared" (5). This was the Yacoubs' nakba: chaos had ensued in their city; Palestinian civilians were met with Israeli military aggression; their properties and homes vandalized and destroyed. In the end, the family's wealth could not save them from the nakba.

Alyan presents a gruesome and graphic depiction of the damage done to the family's property and the trauma inflicted into their memories as a result:

Within days the groves were mangled, soil impaled with wooden stakes, oranges scattered, pulp leaking from battered flesh. Alia cried not at the sound of gunfire but at the smell of the mashed oranges, demanding slices of the fruit. By then, the men who worked for their groves were gone, most having fled, some with bullets nested in their skulls. Hussam refused to leave at first, shaking his first at the sea and land outside of their windows, the view that beckoned them like another room. (Alyan 7)

The author's vivid depiction of the Yacoubs' trauma illustrates the gruesome nature of the nakba. The violence inflicted upon Palestinian civilians in Jaffa was sudden, and unpredictable. The nakba's short-lived span was enough to cause mass displacements and disarray, uprooting families from their lands and homes. Alyan's portrayal of the family's abrupt displacement at the start of the novel establishes the significance of the nakba in the personal history of the Yacoubs, 
just as it has in the lives of many Palestinian families. In Contested Pasts, Katherine Hodgkin and Susannah Radstone argue that evoking financial or political justice all "draw on a sense that the present is obliged to accommodate the past in order to move on from its (itself, of course, a historically specific way of thinking about history)" (Hodgkin and Radstone 1). The way we think, speak or understand the Palestinian-Israeli conflict is shaped by the events we are allowed acknowledge. For many, the memory of the nakba is a constant reminder of failings and challenges to the "morality of the Zionist project," the Arab leadership and people, and the "world about its vision of a moral and just human order" (Abu-Lughod and Sa'di 9). For the Yacoubs', the nakba was the beginning of a long tradition of displacement, exile, and melancholy for many generations to come.

In the years following the displacement, Salma preserves the memory of the pre-nakba past. She spends most of her time daydreaming of returning to Jaffa, and fantasizes of what it would be like to return to her home if her community had not been plagued by strife and violence: “inside, a miracle: everything as she'd left it, even the damp laundry she'd never gotten to hang up" (Alyan 6). Salma's romanticized depiction of Jaffa can be understood as a desire to return to an idealized moment: a time before the nakba. She remembers her homeland as one untouched by the brutality of the nakba. Although there is no hope that Salma's family could once again return to Jaffa, the memory of her homeland is seared into her mind and then passed on to the subsequent generations. However, the loss of her homeland can be likened to the losses she experiences as an expectant mother, early into her marriage.

In Palestinian culture, women are revered as mothers, wives, and caregivers. In particular, marriage shapes the sexual identities of these women, by placing great importance on child-bearing and management of household duties. Although the birth of a female is not 
considered to be shameful, the birth of a male would guarantee the continuation of the family's lineage. In Salt Houses, Salma experiences hardship as a result of her six miscarriages, which prove to be more devastating given the added pressure of giving birth to a first-born male. Alyan captures the inner turmoil Salma experiences as an expectant mother:

There were years between each child, years during which Salma was pregnant and miscarried six times. This betrayal of her body hobbled her; she felt shame at her belly, which stretched only to flatten again. In this way, she failed, and though Hussam was kind, bringing her tea each time she lay defeated in their bed, she knew his disappointment. She'd given him a daughter as a firstborn — the first woman in five generations to do so - and was able to carry only one song in the basket of her womb (Alyan 5).

Salma's six miscarriages makes her feel like a failure to her family. When she is finally able to carry a baby to full-term, she gives birth to a girl. Although Salma loves all of her children, she feels a certain pressure to give birth to a son, who can inherit the family's name, businesses, and who would most likely cultivate and live on the land the family owns. In Salma's eyes, the fate of the family's legacy rests entirely on her shoulder. In the end, Salma gives birth to two girls, Widad and Alia, and a boy, Mustafa.

In an ironic twist of fate, it is Alia and not Mustafa whom Salma appears to favour. Alyan describes the mother's attachment to Alia as "a magnetism delicate and stubborn as cobweb thread" (Alyan 5). She refers to her as a "child of war": too young and innocent to understand the politics of the 1948 war, but old enough to recall the trauma and violence that was inflicted on 
her people in Jaffa. Once they arrived in Nablus, it is Alia who speaks of their home in Jaffa. She constantly asks for licorice sticks and the dolls in from her previous bedroom, but also cries at the sound of fast automobiles that drive in the local Nablusi marketplace (6). Alia's positive memories of Jaffa are the ones which cheer Salma up the most. The mother's heart "stirred" (6) when young Alia recalls tender instances such as when the family would enjoy pomegranates in Jaffa. Pre-nakba Jaffa was memorialized in the hearts of Salma and Alia. The memory of life and trauma in Jaffa is thus preserved by the women in the family and passed on from mother to daughter. The novel emphasizes intergenerational memory, passed on through the female figures, as integral to preserving Palestinian identity and memory of the land. However, not all characters remember Jaffa with such fondness. For Hussam Yaccoub, the memory of Jaffa evokes a spiteful reminder of the unjust price his family had to pay as a result of the war.

The family's displacement from Jaffa to Nablus in 1948 has a profound shift on the family's dynamic, as well as the behaviour and mannerisms of the characters, long after the nakba has passed. When the 1948 war breaks out in Jaffa, Salma suggests that the family temporarily relocate to the city of Nablus for safety. As an act of resistance, Hussam refuses to leave his home, "shaking his fist at the sea and land outside their windows" (Alyan 6). This is a source of frustration for Salma, and the family does not leave for Nablus until their orange groves and house in Jaffa are set on fire and burn to the ground. In one scene, Salma and Hussam are pictured looking out at the "veranda while the children slept, watching the fire streak across their land, listening to their muffled shouts. The smell of burned orange rose to them, scorched and sweet" (6). The apocalyptic scenery emphasizes the degree to which the Yacoubs experience loss. Both Salma and Hussam witness the physical destruction of their home, the scorching of 
their orange groves, and the beginning stages of the Israeli occupation. The event triggers not only the family's displacement but signals the start of their personal grief.

In Nablus, Hussam winces when he hears stories about their old life in Jaffa. His demeanor begins to change and his position as the family's leader begins to shift:

Their father in Nablus was a transformed creature, cheerless, and short-tempered. He no longer made growling sounds when he was hungry, mimicking a lion or hear until they giggled. He no longer asked them to stand straight in front of him and recite Hafiz Ibrahim's poetry, adopting a mock sternness when they faltered. When he spoke with Widad or Mustafa, he seemed to be unfocused. Every evening he listens to the radio raptly. (6)

As the sole breadwinner of the household, Hussam understands the events in Jaffa as a personal defect. In traditional Palestinian culture, a man's honour is bound up with the possession of land and the regulation of family dynamic (Hasso 212). Hussam was to protect his family from the impending destruction which ruined their livelihoods, homes, and future. In his eyes, this tragedy emasculates him and as a result, he carries this shame with him when they relocate to Nablus. In Nablus, Hussam is no longer the playful father with an appreciation for the literature and culture, no longer the father who could expresses his feelings to his children, no longer the husband in a healthy relationship with his wife. All of his time is spent in regret, as he wonders what could have been if only he had stayed and defended his home. Although Nablus is still within the borders of Palestine, for both Salma and Hussam, Jaffa continues to symbolize their version of 
the original watan: a homeland to which they have legitimate claim, and to which they can trace back their lineage.

Susan J. Brison argues that human-inflicted trauma "undoes the self by breaking the ongoing narrative, severing the connections among remembered past, lived present, and anticipated future" (Brison 41). These experiences shatter the victim's “fundamental assumptions about the world" (41) and one's safety in it, while severing the connection between the 'self' in relation to others. Hussam's traumatic experiences during the nakba change him into a man detached from his previous life and present obligations. Particularly, he becomes disengaged from Palestinian politics, arts and culture, all of which once gave him a sense of purpose in life. In Nablus, he makes minimal mention of Jaffa to his children, who have no recollection of the family’s pre-nakba memories. As a victim of trauma, Hussam does not envision a foreseeable future. His distant approach to life post-nakba is a consequence of the trauma he endured in Jaffa. Although traditional Palestinian culture understands lineage as passed down through the father, the connection to the family's original Palestinian homeland and its traditions is unintentionally severed by Hussam.

Hussam's anger builds up over time, especially during his illness. In the middle of the night, Hussam cries out, "They took my home, they took my lungs. Kill me, kill me” (3). Hussam experiences what Hirsch and Leo Spitzer term "trauma dissociation" whereby the “traumatic fragments survive and remain vividly present without being integrated or mastered by the traumatized person" (Hirsch and Spitzer 84). Hirsch and Spitzer regard "trauma dissociation" as an extreme form of "splitting" which characterizes the negative memories of places and spaces (84). Hussam does not have the space or the time to come to terms with the trauma he experiences in Jaffa. The unpredictable nature of the nakba thwarts Hussam away from everyday 
life, where time appears to be quickening and the prospects of safety are lower. Instead, all of his feelings and emotions are sidelined and pushed to the darkest corners of his mind. When Hussam is inflicted with an illness, he attributes the blame to the Israeli military. Hussam genuinely believes that his illness is "tied to the occupation of Jaffa, the city with the peach-colored house they'd left behind" (3). As a result, he groups two difficult experiences together — the occupation of his home and his illness - and attributes one experience as the cause of another. Unfortunately, Hussam dies before he is able to comes to terms with his traumatic past. The memory of the nakba is invoked once again in the wake of the 1967 War, as the next generation of Yacoubs also experience a violent displacement, this time from Nablus, and they, too, find themselves dealing with the long-standing effects of trauma. The loss experienced by Salma and Hussam during the nakba is thus replicated in 1967, an event which Palestinians call the naksa or the setback, in Arabic.

Newly-weds Alia and Atef are the second generation of Yacoubs to experience displacement from their homeland in Nablus. The night before their wedding ceremony, Salma preforms a reading of Alia's coffee cup, and is disturbed by what she sees: a life full of hardship for Alia and her future family, but she also sees travel and good fortune. This reading foreshadows the displacement Alia and her husband face in Nablus four years later, as a result of the 1967 war. But for the time being, Nablus remains Alia's home: the city in which she was raised and later falls in love with Atef, and where she and Atef intend to raise their future family.

In December of 1967, a few months after the Six-Day War, Alia travels to Kuwait City to be with her sister Widad. Mustafa is the last remaining male family member to stay in Palestine with Alia and Atef. To Alia, Mustafa and Palestine are inextricably linked: "Mustafa gone, 
Nablus gone" (Alyan 59). Shortly after the war, Atef and Mustafa are arrested in Nablus, and imprisoned along with dozens of neighbours, cousins, and men from the local mosque:

The charges were spurious and arbitrary: organizing protests, pamphlet distribution, inciting violence. Planning infiltration was the charge for him and Mustafa. It's not true, he'd wept to the guards once they were separated. Yes, they went to the mosque, Mustafa made his weekly speeches. They were angry. But they hadn't done anything. He shook during those unceasing days of prison, having imaginary conversations with Mustafa, who had been taken elsewhere. (Alyan 79)

Alyan provides a detailed account of Atef's firsthand experience of psychological and physical torture at the hands of the Israeli military. In "Trauma Narratives and the Remaking of the Self," Susan J. Brison notes that a primary distinguishing factor of traumatic memories held by victims "is that they are more tied to the body than are narrative memories" (Brison 42). Atef's memories of the 1967 war have less to do with the larger sociopolitical narrative, and more to do with his personal experience of imprisonment and torture. Like many Palestinians, Atef is arrested on false pretenses, and interrogated under torture to elicit any sort of confession, true or false. Atef's sense of self as a patriotic Palestinian is destroyed, leaving him with painful memories of torture and forced confession.

Atef remembers the gruesome detail of his detention, including the method in which he was tortured by Israeli forces: "the electricity, Atef's flesh thrumming until he sang out Mustafa's name, tossed his name to the torturers said his name to every question they asked" (271). The confession unjustly frames Mustafa for a crime he did not commit, resulting in his 
torture and eventual death. According to Cathy Caruth, the trauma inherited by victims does not exist as a record of the past, but "registers the force of an experience that is not yet fully owned" (Caruth 161). When Atef is released from jail, he immediately flees Nablus in order to be reunited with his wife in Kuwait. Atef's escape does not grant him an opportunity to come to terms with the physical and psychological trauma he endured at the hands of the Israeli military. In addition, Atef does not speak of his experience or his guilt, which amplifies his feelings of despair. Atef's guilt regarding his betrayal of Mustafa results in a life-long battle with anxiety and post-traumatic stress disorder (PTSD).

When Atef moves to Kuwait City to be with Alia, he begins to show symptoms of (PTSD) and is advised to seek treatment from his physician Dr. Salawiya. Susan J. Brison notes that trauma "changes the nature and frequency of sensory, emotional, and physiological flashbacks" (Brison 43). Atef is unable to reintegrate into everyday life, as he is constantly reminded of his detention and integration. Atef also carries with him a traumatic burden of false confession, which explains his eventual self-inflicted exile from Palestine. Months following the arrest, Atef is afraid to fall asleep, convinces himself he is having a heart attack, and dreams hauntingly of Nablus and Mustafa (Alyan 79). Brison notes that in order for a trauma survivor to recover, they need "to be able to regain control over traumatic memories and other intrusive PTSD symptoms, recover a sense of control over [their] environment (within reasonable limits, and be reconnected with humanity" (Brison 45). At the suggestion of Dr. Salawiya, Atef begins to write letters addressed to Mustafa in which he expresses his feelings and records his memories of the war, his imprisonment and torture. In one his letters, Atef writes: 
I wake up and it feels like my lungs are dropped in ice and I have to count, one, two three, four, listen to myself taking in air. Sometimes I wonder if this is really the waking world: coffee in a red mug, three children sleeping in three rooms, the television blaring in the background. (Alyan 82)

Although Atef is unable to relay his experiences in Nablus to anyone, especially Alia, he undertakes the task of writing as a form of self-expression. In doing so, Atef engages in the process of what Suzette Henke calls scriptotheraphy. In her book Shattered Subjects, Henke argues that the process of writing through and out of a traumatic experience "could offer potential for mental healing and begin to alleviate persistent symptoms of numbing, dysphoria, and uncontrollable flashbacks" (Henke xii). She views the act of writing as an alternative therapy for victims who suffer from severe anxiety or forms of post-traumatic stress disorder. Atef writes the letters as a form of therapy, he is able to write his way through and out of his trauma in a way that is personal and meaningful way. The act of writing gives Atef the freedom to convey his thoughts, regrets, and fears in a consequence-free environment.

In his essay "The Mind of Winter: Reflections on Life in Exile," Edward Said claims that modern exile is "fundamentally a discontinuous state of being" (Said 440). For many years, Atef is unable to reconcile his traumatic experience with his new-found life in Kuwait. Atef chooses self-imposed exile and is cut off from his roots, his land, and his past. In a letter Atef addresses to Mustafa, he lets him know about his new life in Kuwait City with Alia and his three children. Most notably, he "told him, delicately, about Alia, how neither of them ever spoke of Palestine" (82). The couple's decision to not speak about Palestine to their children is an act of protection and self-preservation. To speak of Palestine would be to speak of the family's long history of 
trauma and displacement. To speak of Nablus would be to speak of past lives and Mustafa's cause of death. These are all topics which Atef feels unprepared to discuss with his children. Writing these letters serve as a form of therapy for Atef who feels unprepared to share his prison memories with anyone. Years later when the letters are discovered by his grandchildren, they function as a way for his grandchildren to connect with their Palestinian heritage. Through the reading of the letters, Atef's grandchildren inherit the memories, confessions, and stories of their grandfather.

The novel highlights the significance of intergenerational memory as a form of the building of Palestinian identity and community. In Kuwait City, Alia's feelings of cultural alienation are amplified when she interacts with other displaced individuals. At a nearby boardwalk, Alia meets Telar, a Kurdish teenager whose family was forcibly displaced in Iraq as a result of Saddam Hussein's brutality. Telar tells Alia her horrific story, in which her family was left to starve, and her community poisoned by chemical weapons (154). This testimony triggers a memory in Alia, reminding her of beloved homeland:

\begin{abstract}
Alia's stomach lurches. Suddenly she wishes the girl would stop talking, would leave her alone. She thinks of the tea bag left carelessly on the kitchen counter. Odd, to be nostalgic for something that has gone nowhere; she feels melancholic thinking of stovetop, her teapot, as though it is a country she has dreamed up. (154)
\end{abstract}

Alia's memory of Palestine is an example of what Svetlana Boym terms reflective nostalgia, the longing "for a home that no longer exists or has never existed" (Boym qtd. in Hirsch and Spitzer 82). Telar's testimony of trauma and exile reminds Alia of the life she lived in Nablus years ago. 
Her memories of Nablus are mundane and ordinary but are strong enough to conjure feelings of nostalgia for the life she lived, unaffected by war and displacement. This memory also evokes an inherited one: "Alia remembers her mother telling her, back in Nablus, that she used to cry for something when they left Jaffa. Though she cannot remember what" (Alyan 156). Alia is reminded of her mother's traumatic experience in Jaffa during the 1948 nakba. In their haste to leave their home, Salma is forced to leave her belongings, including the prized coffee set her mother had gifted her. As married women and housewives, the domestic sphere is an important space for both Salma and Alia. Both women experience a similar loss of home, communal life, and domestic space. The loss of their homes is likened to the loss of a Palestinian watan. Jaffa and Nablus are cities where both women trace their origins, life experiences, and fleeting memories. Most importantly, this instance highlights the domestic nature of the memories that are passed on intergenerationally from woman to another.

The novel underscores the importance of a homeland for Palestinian in the age of modern-states. In "Reflections on Exile," Edward Said observes that the twentieth century is the age of refugees, displaced persons, and mass immigration (Said 174). With the rise of "modern warfare, imperialism, and the quasi-theological ambitions of totalitarian rulers," (Said 174) generations of displaced Palestinians are unable to meet the demands of modern-states that issue citizenship to individuals based on ethnic origin. In Salt Houses, Atef and Alia's children, Riham, Souad, and Karam, retain their Palestinian nationality, despite being born and raised in Kuwait. Since Atef is born in Palestine, his children are also considered to be Palestinian irrespective of their place of birth. However, Alia preserves the Yacoub kinship and the memories, by bringing her children to Amman every summer. 
In the novel, Jordan represents a "makeshift" Palestine for many Palestinians fleeing the region as a result of war. Historically, the majority of Palestinian refugees who found themselves uprooted from their homes and their pasts, settled in places such as Jordan, Lebanon, Syria, South America, and the West. However, approximately fifty percent of Jordan's current population consist of citizens of Palestinian origin. For Alia and her relatives, the choice to move to Amman is simple:

[...] let them go to Amman, the coffee shops and vendors hawking fruit, neighborhoods filled with old friends. Yes, everyone was distraught, mourning the houses and cities they'd left behind, the men beneath the soil. Shouldn't they mourn together? Palestine has vanished for them - this knowledge crept up on Alia slowly, a new death every morning: Mustafa gone, Nablus gone — but they can find the ashes in Amman, collect them to build another life. (Alyan 60)

In Salt Houses, the remnants of Palestinian cultural and familial memory are carried by those who flee Palestine to Jordan, in search of a fresh start. For them, Amman provides the comfort, safety, and security of the pre-nakba past. Alyan's novel illustrates the ways in which the commemoration of the nakba, and the longing to return to one's ancestral homeland is upheld by Palestinians who live in tight-knit communities such as Amman. Alia's desire to live in Amman is not only a reflection of her desire to be around familiar faces, but also to a community and setting which closely resembles the one she was forced to leave behind in Nablus.

Unlike Kuwait, Riham and Souad are surrounded by Palestinians in Amman. Amman is the new Palestine, the girls' "second home," (106) as Salma would say. The girls spend most of 
their time with their grandmother Salma, their aunt Mimi and her daughters Lara and Mira, all of whom share a common lineage of trauma and displacement that is uniquely Palestinian. In Amman, Alia transforms into a person that Riham and Souad do not recognize:

Back in Kuwait she complains of being tired and snaps at then when the television is too loud. She wears slacks and T-shirts, kohl around her eyes. But here, she keeps her face bare, wears short dresses that cling to her thighs. Her skin browns the way Souad does, while Riham's turns red and peels itchy flakes. (111)

Alia dresses and acts in the same manner back when she lived in Nablus — an image so unfamiliar to Riham that it almost feels like an act of "disloyalty to her father" who lives in Kuwait (111). In Amman, Alia is surrounded by familiar faces and socializes in a neighbourhood where the majority, if not all, of the residents are Palestinian.

Riham, unlike her mother and her friends, is not interested in spending her days on the beach or eating shawarmas at a nearby cafés. Instead, Riham is fascinated by her Salma and drawn to her grandmother's religiosity, an attribute she does not find in her mother, Alia, or her father, Atef. Riham believes that her grandmother's faith "lends her a dignified air, authentic and stately in a way other veiled women are not" (Alyan 118). Although Riham does not inherit any particular knowledge on her grandmother's life before the nakba or her parents' life in Nablus, faith and spirituality is passed down to her through Salma. Salma's religiosity originates in Jaffa, where both she and her husband, Hussam, were both devout and practicing Muslims. In the same way Alia inherits memories of Jaffa from her mother, Riham inherits religiosity from her 
grandmother. That summer Riham visits a mosque with her grandmother which marks the start of her religious journey:

Her grandmother gives her a scarf to knot around her head, and a long robe, white with red embroidery. Although it's too large, the sleeves past her fingers, the hem tripping her, Riham always feels strangely beautiful following her grandmother up the stairs, into the suddenly cool, dark entrance. They step out of their sandals before entering the mosque, place them alongside the others. The carpet is scratchy beneath her bare feet. Inside the mosque, women speak with her grandmother eagerly, and Riham understands that Salma is loved. (119)

Riham is mesmerized by the clothing she is given by her grandmother and is equally moved by the atmosphere of the mosque she visits. The mosque is welcoming to both she and her grandmother. Many of the women flock around her grandmother to ask her about her garden, compliment her scarf, or strike up a conversation about their daily lives. The scarf Salma gives to Riham is a symbolic gesture of the faith she will practice when she gets older. Here, the transfer of intergenerational memory from one woman to another is not one of trauma, but one of religious knowledge.

Riham questions her grandmother about her faith in God, and about life's hardships. For example, Riham asks her grandmother whether she prayed for her son Mustafa following his death: "All those deaths, the bloodshed. And I think about what's happening in the world now. Sometimes it seems...". Riham stutters but her grandmother finishes her sentence: "that Allah is cruel" (118). Salma does not answer but encourages her to ask questions about God because "it 
means you're taking Him seriously" (118). Faith's introspective quality allows the adherent to come to terms with the hardship they may face. Salma gravitates to faith in order to seek meaning and to understand the trauma she endures in Jaffa and Nablus. She is able to reconcile with her past experiences in a way that is satisfying for her. Through Salma's point of view, Riham views religious practice as an invitation to look inwards, at process that is incredibly important during her adolescent year. Riham grows up as an observant Muslim and decides to wear the veil, and later marries a doctor who also happens to be a man of faith.

Souad, the second daughter of Alia and Atef, is fed up with the mundane lifestyles Amman and Kuwait have to offer. Instead, she is infatuated with Western music, television programs, and fashion (164). One day, Souad's art professor recommends an art program at L'institut Supérieur des Arts Appliqués in Paris. Souad does whatever it takes convince her parents to allow her to attend the program abroad (158). In Europe, Souad feels like she can reinvent herself into whoever she wants to be. She is not bound to any specific identity or ethnicity. Souad romanticizes Paris, and to a larger extent the West, as a place of reinvention far removed from the war zones and political tensions that have plagued the Middle East for years.

However, Souad's Parisian dream is cut short when she receives a call from her mother, warning her of the impending invasion of Kuwait by Saddam Hussein (162). Her parents ask her to leave Paris and join them in Amman where they will be resettling while her brother Karam moves to Boston to study architecture at a university. Once again, the family finds themselves uprooted from their homes forced to relocate to Jordan for safety and security. Souad, however, is reluctant to join her parents in their new home; she has fallen in love with Elie, a FrenchLebanese classmate back in Kuwait, and plans to spend the rest of her life with him (161). In order to stay in Paris, Souad marries Elie without the blessing of her parents. With no prospect of 
returning to the Middle East, Souad raises her children in the diaspora far removed from Kuwait, Amman, or Palestine, which has become a distant memory. However, Souad learns the significance of Palestinian identity when she travels to places such as Lebanon, the United States, and Kuwait.

The novel underscores the complexity of identity and nationality in places like America, Kuwait, and Lebanon. In American culture, When Souad moves to America, she realizes how arbitrary nationality is. She views Americans as not particularly interested in ethnicity, and she often has trouble explaining where she was from. In America:

You became what you coveted. Memories were short. She met Mexicans, Germans, Libyans, who spoke accented English but responded, From here, whenever asked. Souad become brown. People's eyes glazed over when she tried to explain that, yes, she'd lived in Kuwait, but no, she wasn't Kuwaiti, and no, she had never been to Palestine, but yes, she was Palestinian. That kind of circuitous logic had no place over there. (209-210)

In the United States, whether or not Souad was from Kuwait or Palestine, mattered little, as she is seen simply brown and racialized. The American "melting pot" means that citizens of every ethnic origin identify as American. For Souad, this means that her Palestinian identity is subsumed by her American identity.

In comparison to American customs, cultural lineage is considered to be of great importance in the formation identity in Kuwait. "Kuwait was a place of expatriation," says Souad, "everyone seemed to come from somewhere else. Elie had his Lebanon, Budur her Iraq. Even if a person's heritage was flimsy, unused for years, you were where your father was from" 
(209). Unlike the Palestinians in Kuwait, both Elie and Budur could trace their origins to a singular homeland whose borders and citizenship is recognized by the international community. The Palestinian quest for a legitimate claim to their homeland is not only tied to memory and origin, but is linked to the preservation of human rights and dignity for past, present, and future Palestinians. With this in mind, Souad moves with her children to Lebanon when her husband Elie leaves her for another woman.

Although Souad moves to Lebanon, it is the place where she feels most Palestinian. To everyone "from the cab drivers to the bank tellers, her accent exposes her" (209). Although Souad chooses to distance herself from her family's intergenerational history and displacement, she is unable to rid herself of the Palestinian customs and traditions she inherits during her childhood. In Lebanon, Souad speaks Arabic using the Palestinian dialect, which identifies her as a foreigner. During her visit, Souad recalls missing "the muezzin, the food, even her own tongue faltering in Arabic" (209). Souad's affinity for communal life in Lebanon mirrors her grandmother Salma's pre-nakba memories of Jaffa and her post-nakba life in Nablus. To be Palestinian was to be surrounded by familiar food, religious calls to prayers, and busy streets. Palestinian memory is not merely restricted to trauma, but can extend to culture, language, and tradition. While Lebanon and Palestine share intersecting traditions due to their Levantine influences, Lebanon's history of deep-seated sectarianism means that ordinary Palestinians are often implicated in complex sociopolitical issues and must negotiate their ways through the confrontations.

During Linah's visit to Lebanon one summer, a girl had questioned her presence at the playground after hearing her Palestinian Arabic accent: "You think your people deserve to be here? My mom told me all about them. Palestinians killed my uncle during the war" (230). Linah 
is dismayed by the accusation that she did not deserve to be in the country. She is also unaware of the tensions between some Palestinians and Lebanese during the Civil War in the 1970s. Linah "wanted to say something about how she'd never been to Iraq or Palestine, that she knew only Boston and Beirut, that this was her home in the summers, and Marie must be wrong, because whoever it was that killed her uncle, it wasn't Linah's people, whatever that meant" (230). Linah is taken back by the accusation, and this pushes her away from wanting to be associated with Palestinians or their complex social and political positions. Despite being the daughter of a Palestinian father and an Iraqi mother, Linah lacks the knowledge of the history that inform both cultures. Linah is removed from such history due to her status as a member of the diaspora, yet at the same time bears its burden simply because of her heritage. This inner turmoil becomes the catalyst for Linah's search for identity and meaning. It is through her grandfather Atef's letters that she becomes connect her to her family's Palestinian personal history. Thus, Linah's connection to Palestine is consolidated by her grandfather's memories. The Yacoub family's memories are thus transferred by Atef's letters to the fourth generation, who live in the Palestinian diaspora.

The fourth generation of the Yacoub family are the least connected to their Palestinian heritage. Although they all recognize that they are Palestinian through lineage, they have no memories of the land or the homes of the previous generation. One day, Linah and Zain discover Atef's letters to Mustafa tucked away in the storage room. Although the name Mustafa sounds familiar to Linah (247), she is unable to recall who he is. The letters are written in Arabic, a language which is not a strength to both Linah and Zain. The pair enlist the help of Manar and Abdullah in order to translate the letters and understand its contents. The letters, whose main purpose was to help Atef heal, was now being used to memorialize the family's personal 
Palestinian history. In these letters, the memory of the family's original nakba, the naksa, and the lives of the family members are preserved and successfully passed on to the last generation. Thus, the fourth generation act as witnesses to the experiences of their grandparents and great grandparents. The memory of Palestine is preserved and passed onto the next generation who carry the burden of a complex history of pain and trauma, but also joy and love. For Manar, this inspires a 'call-to-action' and marks the start of her return to Palestine.

Manar, Souad's daughter, is the only character in the novel who embarks on a journey back to Palestine in search of the Yacoubs' historic legacy. Since Manar is born outside of Palestine and has no direct connection to the land, the memories attached to it are passed on by previous generations. As Alia loses her memory, Manar relies on her grandfather Atef to relay the memories Alia had accumulated in Palestine, starting with their family's displacement in 1948, their exile in 1967, and their lives in Kuwait, all before settling in Amman (Alyan 273). Although it is a painful act, Atef contends that "he has to remember for the both of them," meaning both him and his wife Alia. In her essay "Return to Half-Ruins," Lila Abu-Lughod writes on the significance of the nakba on present-day Palestinian-Israeli politics. She writes that for the Palestinians the "catastrophe is not just something of the past. It continues into the present in every house demolished by an Israeli bulldozer... and with every Palestinian who longs to return to a home that is no more" (Abu-Lughod 103). Manar's desire to visit Palestine is fueled by the news she receives of Israel's present-day treatment of Palestinians:

For years she watched news reports of the settlements, the phosphorus dropped over Gaza, camps swelling with eyeless children. Anger held her up with burning little hands, assembled itself into chants of Free Palestine, free, free Palestine with the rest of the 
Justice for Palestine group during Apartheid Week at Columbia. For years she kept a poster taped above her desk of a young man mid-hurl, a stone flying in the air. (Alyan 276-278)

Several decades later, the Palestinian civilians are subjected to a cruel military and administrative rule who are bent on stifling their social, economic, and political growth. Although Manar is encouraged to go back to Palestine to see to the places her grandfather spoke of, she feels as if it is her moral duty to witness for herself their current dispossession.

Manar visits Palestine by flying out to Tel Aviv and landing in Ben Gurion International Airport. She stops at passport control and is interrogated by security on the reason for her travel, her family history, and her involvement in any activist circles in America (284). The most interesting question posed by the security is her family history in Palestine:

He brought her water and crackers. He asked her to write down where each grandparent was born and she paused, uncertain. Nablus she wrote for her mother's parents and, beside it, a question mark. Was it Nablus? That was where they left, she remembered, Had there been somewhere before that? She racked her memory. A faint nausea began to trickle over her like a raw egg. (285)

This passage highlights the irony of the question posed: despite having direct connections to Palestine, she is unable to remember her family's exact lineage. Relatedly, Manar's small scale interrogation reminds the reader of the brutal interrogation her grandfather faced following the 
Six-Day War of 1967; both experiences are meant to be sources of intimidation, meant to discourage entry into Palestine.

In "The Web and the Reunion," Marianne Hirsch and Leo Spitzer argue that "geographical and temporal distance, and the trauma of exile or expulsion, make it difficult to develop an integrated memory of a lost home" (84). Manar utilizes the photographs and descriptions included in the letters in order to locate the origin of her family tree. Though her grandparents' stories were limited, Nablus was the place where they grew up, lived and wed each other (Alyan 287). Manar had formed an unrealistic image of Nablus: "an expansive, generous land peppered with olive groves, valleys between yellow hills. In one of the photos, her younger grandparents grinning into the camera, she could see silvers of indigo sky, bunches of wildflowers" (287). Manar was hoping to fall in love with Nablus the way her grandparents did, but in the moment fails to recognize that the land was subject to a long history of displacement, war, and conflict.

Manar concludes her trip in Nablus by attempting to locate the old home which belonged to her grandparents. In broken Arabic, Manar enquires about the home and asks locals if they might know where it is. After asking a marketplace vendor for some directly, she is led towards some cliffs and inspects every house until she finally finds the one. Alyan depicts a bittersweet moment when Manar realizes she has found her family's old house:

Manar stood there for a long time, holding the photograph in her hand, her grandmother and grandfather half a century younger, a bearded man next to them, his arm casually draped around Alia. Her great-uncle. Mustafa. He'd died a long time ago, before any of them had been born. Manar looked at the grainy photograph, then the real house, the back 
again. She bade herself to feel something, some internal tectonic shift. But she just felt like an interloper, trespassing on memories that had nothing to do with her. (288)

Manar's expects to feel a deep emotional connection to the house her family was forced to abandon and the land upon which it is built on. However, that is not the case because she has not lived in it nor experienced a direct loss on the land. Instead, Manar's connection to the Palestinian watan is strengthened through the memories she inherits from her Palestinian grandparents. The cities she visits in Palestine and the homes she tracks down serve merely as markers of the family's legacy in the region.

On the shores of the Jaffa beach, Manar reflects on her experiences in Palestine, Palestinian nationhood, and her family's own memories on the land. As the waves wash up against the shore, Manar begins to write the names of her family members in the wet sand: "a testimony, she decides" (295). The family tree she draws on the sand symbolizes the historic claim the family has to Jaffa and Nablus. In addition, the name of each family member affirms their presence in the current moment, with Manar: "we were all here... She imagines her whole family standing on this shoreline, in a row" (296). Manar realizes that despite the aftermath of the nakba, her family's lineage continues to grow even if it is outside of the original homeland. At the same time, to live in exile as a Palestinian means that their physical claim to the contested land is not validated.

As Manar ponders her trip, she realizes that the land her family once owned no longer belongs to them. The inevitable truth is that the land will always be populated by another family, or another group of people. Houses will be built, torn down, and rebuilt. Yet when a Palestinian fisherman asks her to leave his shore, Manar starts to tear up. She is reminded of the fact that she 
remains a foreigner in her own ancestral homeland, and the land no longer belongs to her. Alyan artfully captures this moment when she writes:

This is what makes her drop her eyes. It is what pulls her up, rising unsteadily the wet skirt clinging to her legs as she bows her head in apology. A large wave washes over the sand, the water eating her words, her family come and gone in this sea that belongs to none of them. (296)

What remain of the family's history on this land are the memories that are passed down from one each generation to the next. Manar forges a connection to Palestine and her Palestinian heritage through her grandfather's letters. It the testimonies of her grandfather which strengthen her Palestinian identity and connects her to Palestine.

Salt Houses presents a compelling argument for the need to legitimize Palestinian claims to a homeland in the disputed region. Through written and oral records on the nakba, Palestinians have provided testimonies on their lives pre-1948, and how they drastically altered on the level of the individual, the community, and the nation. Like many Palestinians, the Yacoubs experience a traumatic and sudden displacement from their place of origin, with no time to reflect and process their pain and melancholy. I argue that the family's connection to Palestine and Palestinian identity, amongst both exiled and diasporic characters, are consolidated by the memories that are preserved and transferred through oral and written testimonies intergenerationally. These memories have helped victims of trauma heal or make sense of their experience, while strengthening the connection to Palestine amongst the diasporic characters. Lastly, Palestinian identity is intrinsically connected to the land, and the Palestinian desire to 
trace one's origins to a singular watan, in order to create a record of this origin for posterity, is an essential desire for which every human strives for. Perhaps it is the Palestinians' refusal to forget the trauma of their predecessors under the threat of constant erasure, which makes the Palestinian claims for justice so unique. In an unsent letter to Mustafa, Atef reminds us that the "mutiny [of the Palestinians] is our remembering.... This is what it means to be alive" (295). 


\section{Works Cited}

Abu-Lughod, Lila, and Ahmed H. Sa'di. "Introduction: The Claims of Memory." Nakba: Palestine, 1948, and the Claims of Memory, edited by Lila Abu-Lughod and Ahmed H. Sa’di, Columbia University Press, 2007, pp.1-24.

Abu-Lughod, Lila. "Return to Half-Ruins: Memory, Postmemory, and Living History in Palestine." Nakba: Palestine, 1948, and the Claims of Memory, edited by Lila AbuLughod and Ahmed H. Sa'di, Columbia University Press, 2007, pp.77-104.

Alyan, Hala. Salt Houses. Houghton Mifflin Harcourt Publishing Company, 2017.

Brison, Susan. "Trauma Narratives and the Remaking of the Self," Aftermath: violence and the remaking of the self. Princeton University Press, 2002.

Caruth, Cathy. Unclaimed Experience: Trauma, Narrative, and History. Johns Hopkins University Press, 1996

Gelvin, James L. "The Palestinian Israeli Conflict." The Modern Middle East: A History. 4th ed., Oxford University Press, 2004, pp.230-253.

Hasso, Frances S. Resistance, Repression, and Gender Politics in Occupied Palestine and Jordan. Syracuse University Press, 2005.

Henke, Suzette A. Shattered Subjects: Trauma and Testimony in Women's Life-Writing. St.Martin's Press, 1998, Hodgkin, Katherine, and Susannah Radstone. "Introduction: Contested Pasts." Contested Pasts: The Politics of Memory, edited by Katherine Hodgkin and Susannah Radstone, Routledge, 2003, pp.1-12. 
Humphries, Isabelle, and Laleh Khalili. "Gender of Nakba Memory.” Nakba:

Palestine, 1948, and the Claims of Memory, edited by Lila Abu-Lughod and Ahmed H.

Sa'di, Columbia University Press, 2007, pp.207-227.

Hirsch, Marianne, and Leo Spitzer. "The Web and the Reunion.” Rites of Return: Diaspora

Poetics and the Politics of Memory, edited by Marianne Hirsch and Nancy K. Miller, Columbia University Press, 2011, pp.1-12.

Hirsch, Marianne. Family Frames: Photography Narrative and Postmemory. Cambridge, MA: Harvard University Press, 1997.

Johnson, Nuala C. “Locating Memory: Tracing the Trajectories of Remembrance.” Journal of Historical Geography, vol.33, 2005, pp.165-167.

Khalidi, Walid. "Why did the Palestinians Leave, Revisited." Journal of Palestine Studies, vol. 34, no. 2, 2005, pp. 42.

McCullough, Kate. "Displacement as Narrative Structure: Refugee Time/Space in Diana AbuJaber's Arabian Jazz." American Literature, vol. 83, no. 4, 2011, pp. 803-829.

Said, Edward. "Reflections on Exile." Reflections on Exile and Other Essays, edited by Edward Said, Harvard University Press, 2001, pp.173-186.

"The Mind of Winter: Reflections on Life in Exile." Harper's Magazine,1984, pp. 49-55.

Sanbar, Elias. "Out of Place, Out of Time." Mediterranean Historical Review, vol. 16, no. 1, 2001, pp. 87-94.

Sayigh, Rosemary. "On the Exclusion of the Palestinian Nakba from the "Trauma Genre.”Journal of Palestine Studies, vol. 43, no. 1, 2013, pp. 51-60. 
Lahalih 36 